\title{
AN ORIGINAL STUDY OF MESQUAKIE (FOX) LIFE IV
}

[Continued from Vol. X/X, No. 5, July, 1984, issue of the Axrals]

Thursday evening, August 30, 1928.

Mr. Harlan: Young Bear, I would like to learn how an Indian boy in the old time got his education. How was he taught, what would be his experience from the time he was a little boy until he got bigger and bigger, and of enough importance in his tribe to take the part of a man? What, in old times corresponding with our white folks' system of education, existed in the Mesquakie life?

Young Bear: As for back as I can remember, I will say when I was three or four, and going back to the very beginning, the things that I learned I still remember, and some of these rules that were given to me I still observe. From the very beginning (and it is like any other child is) that they teach them to do certain things. Around the lodges they are taught to do and they are made to do these things, and they should know how to do them. And later on they are taught the difference between right and wrong, and of course they are punished if they do not mind. Between four, five and six years of age $I$ was taught many things that children should not do, and what they should do, towards others and towards living things, and so, from that age, when $I$ do not mind them, cold water is thrown on me as a form of punishment. And from six years on up to the young manhood I was made to fast. In fasting I do not get anything to eat from early morning until night. When $I$ do not mind when they tell me to do a certain thing, and I do not do it, I am made to fast all the next day. I was not given any food until the sun sets, and throughout the winter I was made to fast, so I eat only once a day. When I do not obey I am made to fast, and the second time $I$ do not obey the same thing-it is the second offense--then I am made to fast two days, and so on, and so it was this form of training that $I$ received from $m y$ parents, and it was the same with any other Indian children.

The first bow and arrow that was made and given to me was 
when I was eight years old. Before I was given this bow and arrow I was told not to shoot at the dogs, horses, or people, and I must not try to shoot at anything, at any property, or any object that I care to keep. I was taught to shoot the birds and rabbits and things to eat, and only when $I$ go out to look for these things, and when $I$ make a kill and come to the lodge I give them to my parents.

'The first time that I ever handled a gun was when I was a young man. The gun, an old musket, was given to me and they didn't have, in those days, shells. I had to load it. So one day I wanted to learn how to fire the gun off. I was afraid at first. However, I picked up courage and took the gun out. I saw some prairie chickens-in those days prairie chickens were numerous, also ducks. One day the men were away. They went to the city of Tama to receive their annuities, and that day I went out. I took this gun along, and went out alone. When I saw the prairie chicken sitting on the tree I sneaked up underneath the tree and aimed, and just as $I$ was about to pull the trigger I turned my head away, and I was afraid to fire the gun, and so I tried it two or three times until I had the courage to pull the trigger and when I did I didn't know what happened. I didn't know whether I hit the prairie chicken or not, but that prepared me to start out with my gun, and from then on I got up early, and had to go out hunting before I got anything to eat.

All of the men in those days were sort of having competitions among each other. He who should kill the most ducks and prairie chickens and so on, so each morning before daylight all of the men folks were away hunting. They did not come back home until long after dark. They would be away all day, and so I did the same thing. I would get up early in the morning and start off and I would not come back home until late in the evening. Of course, in those days, around 'Tama, I never had any experience with the deer.

The men folks do all the hunting, and they take care of all the ponies, and that is all the men did, so each day they would go out hunting. That is the only work they do. The women folks take care of the lodge. They keep up the lodge and the yard, they go after the wood and take care of the stock, make mocca- 
sins and things to wear while the men are out hunting, and so the changing conditions-things are changed-nowadays the men want to work. 'They go out in the field and take care of the crops.

The old people of our tribe do not speak the English language because they did not go to school. Some of the tribes are far more advanced in this line, even the little children speak English, so they have lost their own language. Our people do not lose it, because they speak their own language as their everyday language. So when I was a young man I learned the different things that my people taught me. My father was chief, and therefore the old men of the tribe would gather together often in the evenings at their lodge and they would talk over their old times and their old customs and their habits and their tribe and treaty rights. 'They would tell over a different thing each evening. Some members of the tribe would come and listen, and of course the children who listened would sit still. They are taught to listen to every word that is said, they could not even turn their head, they could not even have anything in their hands to play with, they would just have to sit still and listen and look at the fire before them. If they turned their heads or even moved a little, then they were regarded as not being attentive -not listening. They were scolded by their parents. In this way they just have to listen and learn. These old men talked of their younger days, and they would talk of their old people and their younger days, how they used to go out to battle with the hostile tribes. They would talk of their experiences while in battle, and each man would tell of his experience.

They would tell their beliefs that they had in those days, and the rights and obligations that they carried and so they taught each other. It is a belief that a warrior who goes forth to meet the enemy should never turn his back to the enemy-that he should face him. Whenever one of our men would be killed his relatives would go to look over the body and to look at the wound. If the wound was in the forehead or the breast they were glad, because their dead relative was brave. If the wound is on the side, he must have fled, and of course if the wound

1Push e ton e qua was born at South Amana, Iowa County (Poweshiek's village) in 1839 , and he died November 6,1919 , on the so-called reservation in Tama County, Iowa. 
was on the back, that is a sign of cowardice, and that was the belief that they had.

In the old days our people had experienced hard times. They were constantly in danger of being attacked by other Indians, and so the men are tanght to be alert and watchful, and to observe every sign and know it. And so the custom in those days was that the people should rise with the daylight and when the sun sets every one in the village should be asleep. And many times in the villages the men are sent out to be on the lookout and to see if they can find any strange signs, and so it is that their men are always prepared and always ready to answer any call to protect their homes. Each morning, very early, when daylight is just breaking, one of the men-the old men-would walk back and forth along the village and shout to the people to arise and to be up and around. They would shout for the men to be prepared for before long the enemy may be coming upon them, and so when the sun sets and darkness is upon them, then the same man walks back and forth in the village, shouting for every one to be in the lodge-to be with their family-particularly the children, they should not be outside, but within the lodge, because the belief was that in the darkness there lingers disease of various kinds. So if any of the children do not mind -if they go out after dark, and then they are taken sick-that was a belief they had. And so it was a custom that they should always have some one morning and evening to walk back and forth along the village shouting these very things. That was what Mr. Harlan heard Wild Cat shouting, he was observing one of our old customs.

There were a great many customs that they had in those days, even in their form of dress. They cannot wear most anything that they please, but they got to accomplish a certain deed in order to wear a certain article. The warriors who had accomplished greater deeds than any one can wear the eagle feathers, or the war bonnet. $\mathrm{He}$ is the man that has a right to wear them. Even the feathers-the trail of feathers cannot be worn, but an old warrior who has seen many battles, and has conquered many enemies-he is entitled to wear the trail of feathers. The red feather worn on the head-the single red feather-means that 
this warrior has conquered his enemy at one time, and so as a sign he wears his red feather. Each article that they wear is a sign of some deed they have accomplished. Even the flowers and leaves are used.

When the men are out on scout duty they are always on the lookout for the enemy, so that is a branch [of a tree] they break -a branch [camouflage] in order to look over a hill or anything that has to be gone over. They are careful not to walk in plain view, but they must first peep over, in order that they may not be seen by the enemy, and so they take these brushes. They would move them ahead of them carefully, and if they see an enemy without being seen, and go back to the village and notify, their people, then he has a right to wear a leaf or a flower on his head. There are many things that they had. Even the paint has some sign. And so today there is peace everywhere, and these things are forgotten.

It would take many hours to tell in detail every one of our customs that our old people have followed and have taught each other to observe. Of course, nowadays we do not pay any attention to them. However, the dress and the things that we wear had signs, and we cannot wear most everything that we please in those days. A great many things can be told why they should not be worn. The belief that they had was that through the Great Spirit these things were given and they are blessed by Him. Many of the things are sacred to us, not because they want to show off to their people that they have done this or that, or that they want to be conspicuous, but because the Great Spirit had willed and heard these things, and in order to please the Great Spirit He must be shown that they have observed the things that $\mathrm{He}$ has given to them. The sacred things that they had were given to them. Fior instance, before going to the wars sacred packs were used in those days by warriors in taking the men to battle. In order to be a leader they must have a sacred pack, a ceremony should follow, and the songs, and there should be uttered by the leader to their men out into the battles, and then they did not lose many men. They did not make any mistakes. For the safety of their people they must follow these things in a spirit of prayer. They must ask the Great Spirit 
to guide them. Many of these that were practiced have been forgotten and discarded. They are now sold to various men, mostly collectors, and so you will find these in many of your museums and many of the garments that the warrior wore are found in many of the museums. Our people have sold most crerything that they had. Jirom the very beginning when white men stepped on our soil, our people inhabited the whole area, and then gradually the white man has taken our country away from us and have bought everything, and so we do not have anything left. Even the paint he bought. We do not use the paint any more. Who sold the paint we do not know, but we see white people using it.

I am at loss to know what you people want me to talk about. I am talking about most anything that comes into my mind. If any one could ask a question then I would know just what is wanted.

Mr. Harlan: Last spring the Mississippi Valley Historical Association met with the Historical Department and Drake University, ${ }^{1 n}$ and you and your people helped the Historical Department to entertain that association. There was at that time a story that you told of a tradition-I think you would call it a tradition-that was commented on by a number of the delegates and visitors there as being a great lesson in the training of a boy's aspiration and I don't know how to characterize it, and as we did not take it down to indicate what it was, I am going to ask you to tell it now. It has to do with a hero in your minds, and the thing to remember was that he had a bow, and a spear in the end of the bow, and he had his arms crossed above that spear, and that attracted the attention of the boy. Now; the boy had a conversation with his father or grandfather, and the boy said he wanted to look like that man. I want to see if we can have that story recorded.

Young Bear: The story or the legend ${ }^{2}$ that I will tell was a legend that I heard when I was a boy, told by one of the old men who came to the lodge to tell these stories, so I will try to tell as much as I can remember. It tells of a little boy who lived with his grandfather, and of one of the greatest warriors the

$1 \mathrm{a}$ See ANnals of Iowa of October, 1932, page 403.

$2 \mathrm{~A}$ portion of this legend was published in the October; 1933, ANNals, Vol. XIX, p. 123 , but it lacked the elaboration and the teaching contained in this
version. 
tribe had. This warrior, when he was a very small boy, would go out to hunt and when he killed a bird he would pull all of the feathers and prepare the bird in such a way and hang it on a tree. At times he would kill many birds. He would do the same to any one of these birds-hang them on the tree. When he killed a rabbit he would do the same. When he became a young man and began to kill bigger game, deer and bear, he would do the same thing. He would prepare the game and then leave it on a tree. In this way he helped those who are having a hard time, who are weak and cannot make a kill for themselves. He would get the fowl, the eagle, and many of the birds he hung in that way. And so when he became a man some one of the spirits spoke to him, that he had indeed helped a great many who could not get out to make the kill themselves. And so he received the blessing that he was to be a warrior, and he goes out, after being blessed, to battle-to meet the enemy, and each time he was successful, and eventually he was the greatest warrior the tribe had. He was entitled to the garments [tokens and ornaments] he wore through the deeds that he had done.

At one time the tribe had a dance. At this dance the whole tribe gathered together at one great lodge to take part in the dance. Many of these warriors came to the dance, and as he came near to the lodge he stopped at the end of the lawn. In those days the grass was stripped, and it was bare ground, and at the edge of the bare ground there was a mound [ridge or bank] all around the lodge, and so he stopped, with his bow, and leaned against it. And so it happened that the little boy came to see the dance and saw the dancers. He admired every dance very much, and he looked around him to see the men who were watching the dance. There was one man that he noticed particularly-the great warrior. As this great warrior was standing watching the dance, this boy noticed him and admired him very much. He noticed a buffalo robe that he wore, and he noticed the bow that had a spear at the end, and this man was leaning against the bow. And the buffalo robe he wore had a basswood bark tie [for a girdle or belt]. And as this boy was watching this great warrior he admired him very much. Indeed, he wanted to look like him. Eventually he forgot about the dance. 
He stood there watching this great warrior. And so when he went back to their lodge he asked his grandfather to make him a bow with a spear point at the end. His grandfather replied, "Grandchild, I will make the bow." And the small boy asked his grandfather, "And you will make me a buffalo robe, and you will also get me the basswood bark so I can tie on the buffalo robe?" And then his grandfather understood, and he said to his grandchild, "Grandchild, what you have asked is too much. You cannot imitate any of our great warriors. You cannot look like a warrior who is the greatest warrior that we have had. It is through following the teachings and observing the rules that are given to you that you will earn the garments that the great warrior wears, and then after that you will go forth to meet the enemy, and if you prove to be a brave warrior, and come back to your people with greater deeds than any of our warriors, then you can wear these garments. And then indeed you can look like that warrior."

The little boy was discouraged. He knew it was hard for him to wear these garments and look like the man he admired. And so he sat for a long time, and as he had asked his grandfather he could not back ont, and so he made up his mind that he will some day when he becomes a man, wear the very garments that this great warrior wore, and so he asked his grandfather what he should do. "First you must pray the Great Spirit, and you must love all people. You must love every one-all the living things. You must, from morning to the time you go to sleep at night, think of the Great Spirit, and pray to him to help you. You must fast occasionally, and go out into the woods and pray, and must continue to do this until you hear some voice that you have been blessed." And so the little boy began, from year to year until he was a young man. Sometimes he would fast for days at a time-perhaps two days, four days, six days, or eight or ten days, and still he has not heard the voice. But one time he fasted for many days, and at the end of these many days he heard a voice which spoke to him. "Grandchild, you must go back to your lodge and partake of the food which has been cooked for you. Indeed, you have received the blessing. Now you have earned for yourself the things that you have prayed for." 
And so he arose and went back to his lodge and told his grandfather. His grandfather, with a great joy, gave him the food, and then he told his grandparent that he should go out among the warriors, but if there was danger he should go out with great joy, because he must earn the things he wanted to wear, and so he goes out. And at each time the warriors came back with words of praise that the young boy was indeed very brave, that he was not afraid of any danger. He was not afraid to meet the enemy. Eventually the young man became so brave, so well known, that he became the leader of several of the war parties. And he from time to time accomplished great deeds, and so eventually he would go out to lead the war parties. He became a leader. He became well known even among his enemies as a great warrior. He was feared by his enemies. When he led a war party he was successful. He accomplished great deeds, and so at last he has earned the bow, the buffalo robe, and the things that he wanted to wear. He was loved by the whole tribe. He was respected and honored by his people.

At one time when he was alone he went to his enemy. He came upon the whole village. He came in their midst, and at that time they were having a pipe dance. There was only one entrance at this lodge and he came into the lodge at the main entrance, and he stood there. 'There before him sat the great warriors of that tribe. He looked at each one. They were in a circle, and each warrior as he looked upon him was not equal to him. He cast his eyes around the circle and these warriors, as he looked at each one, could not be equal to him-that he could overcome each one. There is one particular warrior who was at the very center of the circle, that he is not so sure about. As he looked around these warriors they struck up this dance. Each warrior took his pipe, and as each warrior came up to offer his pipe they cannot always-and there came up those who cannot offer the pipe - they passed him. And so it goes on until it came to the warrior at the very center of the circle. He took the pipe and circled the lodge, and as he came upon this great warrior who had been standing at the entrance he offered to him the pipe. So this great warrior accepted, they immediately

\footnotetext{
3Not having qualified by deeds of valor.
} 
started to fight. And then as they were fighting he-the warrior who had stood at the entrance-overcame the other. And so all the warriors were afraid, and wanted to flee, and as they were trying to flee, the great warrior fought each one and he almost ovcrcome every one until there was so much confusion and noise that the whole tribe was aroused. They wondered what was the matter, and they saw that their warriors were fighting this one single warrior, and so they surrounded him. This great warrior remained in the lodge. In this confusion he was lost within the lodge. They surrounded the lodge so that he cannot escape. And they had the warriors to search the lodge. They searched and searched. They boiled the water, and they threw this hot water everywhere on the poles and on the mats, and on the back of the benches, and they cannot find him. 'They overturned everything, even then they cannot find him. They knew he had the power to change himself into almost anything, and so they destroyed almost everything that they laid hands on. During this search there was a black dog who was sleeping underneath a bench, and each time some one would try to take the bench away this dog would growl, and so they did not dare to take it away. And there underneath the dog lay a serpent, and this was the great warrior. He had changed himself into a serpent and hid under the dog. At the end of the search the whole tribe gave up the search and went back to their lodge. And so this great warrior made his escape and went back to his people. That was how this little boy earned himself the things that he wanted to wear.

Mr. Harlan: May we have your comment on this, Dr. Gilmore, or whatever course you may see fit to take?

Dr. Gilmore:" You had Young Bear telling a little of that course of education of the boy, and following along through the time of his childhood, his youth, through his manhood, and finally in this story. He has given the story to show what the aspirations of any boy might be when he is to be something in the world, who had not been trained for such work. The story, as you will notice, is partly allegorical, of course, but it is meant 
to be told of a boy's opportunity and is a means of teaching to overcome obstacles and hardships in coming to a man's place in the world, to accomplish great deeds. There is, later on in the story, the place where he tells of the work-of the boy's having certain chores to do, and this increased in responsibility and worth as he increased in years. That is the form of teaching in all the tribes so far as I know, and the tribes in the Missouri region as well as the tribes of the woodland regions. Boys and girls both are given proper little duties at first as children, and these increase until gradually they get into the full work of adults. Then I wish you would notice that he spoke of the difference of labor between men and women. In the old time the women were the home makers, home caretakers. They did all the housework while the men did the work of defense from enemies, and from any other danger, and the providing of food, that requires the most arduous labor. I wish you would notice that. And the Indians hunted then as they work in the field today. It was hard work. You notice he said the men got up early in the morning and did not return until they got something to eat, and came back late at night, with whatever they were able to get.

I wish you would notice another thing. They continuously said they were taught to have regard for all living things. When he said that he meant not only human beings, but all the animals and plants. And that was the common teaching for all the children-to have reverence for life, for all living things. The children were taught that all living things are precious, are part of the Great Spirit Life, and by that we are all partners together, and the continuous teaching of the people is to have proper reverence for every living thing, no matter how small, and the greatest of things and the least of things are to be regarded as partners with us in the mystery of life, that they are our friends, and we are all to try to help each other. They said the great warrior had helped all living things, and so he was helping the birds and the animals, and had regard continuously, all his life, for all living things, and that he did not destroy anything except for a purpose. It is necessary sometimes to kill. We kill plants and animals for our own use. Nothing is to be killed wantonly. There is such a thing as going out to kill animals just to be killing something. 'That is not human. 
Here is a little thing in the teaching of conservation to children in the matter of even the wild flowers, common to all the tribes I am acquainted with, and I take it that such teachings were common to these people. Children are taught that they should not pluck the wild flowers or destroy any plants uselessly. I have seen a child going along with a stick, carelessly flipping off the tops of the plants, and he was chided for it, the others saying he must not do that. "If you kill the flowers there will be no babies--the seeds-and if you have no flower babies, then after awhile there will be no members of the flower nation, and if the flower nations are gone the earth will be sad. It is a horrible thought to any Indian or to you or to me to think of the overthrowing of any creature of nature-to think of making extinct anything that the Creator has placed in the world.

Mr. Harlan: First, George, ${ }^{4}$ this comment of Dr. Gilmore's, will your father be interested in having it interpreted to him, or will you do that later, so he may have the benefit of what he said?

(George speaks to his father, and Young Bear answers him.)

Mr. Harlan: It is up to you to do whatever he suggests. Let me explain to our friends that one of our faults is that we go to our Indian friends, pump them dry of all the good in them, and then don't give anything to them. So, when anything transpires that is beneficial or interesting to him, I have tried each time to give that interpretation back to the Indians, so for that reason, I say that Dr. Gilmore's comments on this talk of Young Bear will be a blank thing until George tells him, Young Bear, what was said. That reciprocity of mere courtesy hardly ever comes from us. It is very seldom that any white person thinks of paying back. They ask a question, get their answer, then the white man turns his back and leaves without paying back the debt. So for that reason, except that I do not want to bore our friends, I would like to have George interpret in Indian Dr. Gilmore's talk. If I were alone I would have this speech of Dr. Gilmore's interpreted to Young Bear, but it drags a little with a white audience, who is accustomed to have things move rapidly,

4George Young Bear, son of Young Bear, is a graduate of Haskell Institute and was the interpreter of Young Bear's language and of all the Englislı spoken to Young Bear. 
so if George will say that he will give his father the benefit of it this evening, then well and good, and we will go on to something further. Will you do that, George?

(George speaks to Young Bear.)

Mr. Harlan: George, is that Dr. Gilmore's speech or mine? George: Both.

Young Bear: I want to remind Mr. Harlan that I told him this morning about the trees, the flowers, the grass and all the plants, in fact everything that we see. We should regard them all as being one of us, and that is even if we do not know one blade of grass, we do not know what it is, but some one does. In each family in all the tribes there are certain family secrets that they do not tell to any one, so they keep these within the family. Even if there is one person in the tribe who is suffering they go over to heal him, and when they do that they do not tell, but they help toward relieving the suffering, and in learning the secret that should be learned they carry it from generation to generation within a family. And so it goes on, so what we believe is, if we do not know, some one does.

Mr. Harlan: I should say that is native conservation: In his story this evening-rather, his telling of the way they get up in the morning and go to bed in the evening, he alluded to Wild Cat and myself.

I had been going down a good many years to their powwows at Tama, when they have visiting them one or more from friendly tribes of Oklahoma, Nebraska or Wisconsin. Among those who live among them at Tama part of the time is a Winnebago, or a half Winnebago, who they say is not very smart. One night Bill Leaf, who talks English as well as I do and talks Indian as well as George does, was sleeping in my tent and I took advantage of his ability to speak both languages. One morning before daylight I heard what sounded like a man warning everybody of fire. The tone of his voice and his speed made me feel that I ought to do something, and I didn't know what to do. I woke Bill and asked him what was going on. He said "Nothing." I said "What is this talk about?" "Oh, it is just old Wild Cat talking Winnebago." I heard the voice grow fainter on down the camp for a half mile. After awhile he came 
back-I knew it was a different kind of talk. This time as it grew louder, I woke Bill again and asked "Now what is he • saying?" "Well," he said, "he is talking Mesquakie now." But that didn't satisfy me, and I said "Explain what he said." "He says, 'Get out everybody-get up. Let's make the day as long as we can while our friends (visitors) are here." 'That's the joke they have on me. My own gratification in knowing these things and having them recorded is great. I just feel it must be to every one else, and for this reason today's experiment is being tried. I hope it will be enjoyed by every one who is here. If it could be turned to you and then taught as Indian Life to the children-this record directly from these people, surely would be a contribution.

I wonder if any one else has a request that we can make through George's interpretation to his father, or direct to Dr. Gilmore, and have it interpreted to Young Bear?

Young Bear, the other day when Miss Rhode and you and George and I were talking about different Indian tribes who one time lived in this part of America, there was a tribe we mentioned, the Missouries, and I don't believe that we had called the name, but you said to me "What became of the Missouries?" and I said "We will ask Dr. Gilmore."

Dr. Gilmore: The Missouri tribe is one of the tribes that called themselves the Niùtachi, but they are called by a name that sounded to white people like Missouri. White people had not yet known any tribe of the Siouan stock, and I think those white people, that is the southeast people, called them the Missouri or something that sounded like that, I think the great river that came down through the Missouri country they called the Missouri River. Of course that name of the river followed on up the whole course of the river, the same as we have it on the map. By one misfortune and another, disease and war, they were so much weakened that finally they were thrown into the same nation as the Otoes, and so ever since it has been the OtoMissouri tribe, similar to the Sac and Fox. The white people call them the Missouries, so they lost their tribal identity in that way. They have just been absorbed with the Otoes, and the Otoes were in southeastern Nebraska. The Missouries had been 
in this country in what is now the state of Missouri, and the remnant of that tribe was taken over by the Otoes. Then the Otoes were finally removed to Nebraska, and afterward carried into Oklahoma. So what is left of the Missouri tribe are in with the Otoes in Oklahoma.

There is one more thing I would like to tell. He mentioned sending the boys out to pray. It is the custom of all the tribes I know to send out boys of about the age of fourteen years to fast and pray until they had visions which they believed to be a sign by Deity of a blessing. Among the Omahas this was the prayer they kept continuing during the fast: "Waukonda, we are poor and needy." They would cry and wipe the tears away with their hands, putting their hands into the dust, and again wiping the tears, and the dust and tears made mud, and in that condition of fasting they went away into some lonely, wild, uninhabited place, until finally there would be sent to the boyhe would fall into a trance, and would see a vision of some bird or mammal or whatever element of nature had been given to him. If he saw a bear, he was to be a bear favorite-the vision of the particular animal, whatever it be, or some other thing of nature. Now, these visions continued through the span of the boy's life, and he would receive the vision all the rest of his life, and conform to the teachings of this cult. He had nothing to eat all this time, but he would have a little fire upon the hill. Overlooking the Missouri River about twenty-five miles south of Sioux City, on the Nebraska side there is a very high cliff overlooking the great expanse of the Missouri on the Iowa side. I can imagine the feelings of a boy out in that place-they called it the Hold Fire Place. He would be out there alone, no other human being, only the wild animals and birds. In daytime he could see the sun, and at night the stars would come out, and he would see the passage of the day and night, until finally he would fall into this trance, and have the vision. He might see a vision pertaining to the buffalo. Then his vocation in life-lie was called to be a surgeon, and so he would go back and report to the proper fraternity according to his vision, so this boy would report to the buffalo fraternity, and so he would be accepted as a student in surgery. He would be taught all of the methods of 
surgery of that fraternity. This is part of every boy's training - to go out and fast and pray for the favor of Deity.

Ten or fifteen years ago $I$ used to see a number of circles on top of the hill, and it is now the same. One of the men had been back up there. As they would come back each spring they would make their sacrificial fires and revere their old visions of their boyhood. I have seen only one. But because of the death of these men they are no longer present.

George interprets to Young Bear. Young Bear speaks: It is the same way with many tribes. The old people are passing away, and along with them there is a belief that we have, and the customs and the knowledge that they have had, will pass away. We have known our old men and our old people that are passed and gone, and along with them are many of the secrets, many of the teachings and many of the customs and rites and the beliefs that we had have passed away with them. Today our young children are going to school and our young men are going out into the world among the white people and they have become white people, they do not know our race, they do not know the customs and teachings, and so the last of our old men will soon be gone, and then these things that we are talking about will be forgotten.

Dr. Gilmore: It is a sad thing that we should have taken the land that we have taken-land dearer to them than we can know. We are not children of this soil as they are. Our ancestors go back to European countries. So we are losing ourselves in not pursuing these things we have just now spoken of. But these young people of the Indian race are going out among us and learning a little of what we have, but they are being uprooted from everything in connection with their own soil. That is what Americanism is. We have to teach love of America from the beginning of Indian life. What we have heard of Americanism the last few years is that you teach history. You cannot make America out of history by teaching only the constitution. It comes of being in America and knowing the humanity of the classes and races on American soil.

For a short while I was visiting with one of the tribes of the Iroquois nation. That people had many beautiful customs and 
religious services for all occasions of the year. They have five thanksgiving ceremonies, beginning first with the strawberry festival, and so it continues on through, when other fruit ripens. While I was there this summer I was out picking some wild strawberries, and one of the children going to our school, learning of our ways, and not learning of their own-they are losing the teaching of their parents-teaching that would be good for them and for us. So these children were picking strawberries there, and one older girl talked to me. She was a schoolgirl, and there was an indication of the white customs now obtaining everywhere, and losing everything of their own people, and I said, "Do you know that your people used to have, in the old times, a strawberry festival when strawberries were ripe?" She said she didn't know that. I told her something about it, and I said, "I think it is a pity that you young people should grow up and not learn anything of the old time customs of your people. I think you ought to talk with your grandmothers and grandfathers and their people and keep the remembrance of those good customs of the old times." She said, "I should worry -this is modern."

Mr. Harlan: Will you tell your father that, George, then we will close our talk?

(George interprets Dr. Gilmore's talk to Young Bear.)

Mr. Harlan: Well, I feel like we could just keep this up all night, but it is ten o'clock, and I think as fast as we can get up and get started we will go home.

We are again under obligations to our kind and attentive friend, the barkeeper of the Steamer "Iowa" for a package of St. Louis papers. By his attention we have frequently been enabled to lay items of news before our readers several days in advance of the mail. Were we not afraid of incurring the displeasure of the sensitive portion of our Washingtonians, we would wish him great success in his business, but we must keep silent.-Bloomington (Muscatine) Herald, April 28, 1843. (In the Newspaper Division of the Historical, Memorial and Art Department of Iowa.) 
Copyright of Annals of Iowa is the property of State of Iowa, by \& through the State Historical Society of Iowa and its content may not be copied or emailed to multiple sites or posted to a listserv without the copyright holder's express written permission. However, users may print, download, or email articles for individual use. 